\title{
Ultrasonic therapy modulates the expression of genes related to neovascularization and inflammation in fibroblasts
}

\author{
Terapia ultrassônica modula a \\ expressão de genes relacionados \\ à neovascularização e \\ inflamação em fibroblastos
}

Priscila Daniele de Oliveira Perrucini $\mathbb{1}^{1 \star}$

Rodrigo Franco de Oliveira (1) ${ }^{2}$

Flavia Beltrão Pires de Medeiros (10 ${ }^{1}$

Larissa Dragonetti Bertin (1)

Deise Aparecida de Almeida Pires-Oliveira (1) ${ }^{2}$

Regina Célia Poli Frederico (1) ${ }^{1}$

\footnotetext{
1 Associated Master and Doctoral Program in Rehabilitation Sciences, Universidade Estadual de Londrina (UEL) and Universidade do Norte do Paraná (UNOPAR), Londrina, PR, Brazil

${ }^{2}$ Centro Universitário de Anápolis (UniEVANGÉLICA), Anápolis, GO, Brazil
}

Date of first submission: December 8, 2020

Last received: March 19, 2021

Accepted: March 29, 2021

Associate editor: Talita Gianello Gnoato Zotz

*Correspondence: prisciladanielefisio@hotmail.com

\begin{abstract}
Introduction: In the rehabilitation of musculoskeletal injuries, ultrasound is widely used in clinical practice. Objective: To evaluate the effects of pulsed ultrasonic therapy on the viability and modulation of genes involved in inflammation (IL-6) and neovascularization (VEGF) processes of L929 fibroblast cells. Methods: For irradiation with ultrasound the cells were subdivided into groups: G1 (without irradiation), G2 $\left(0.3 \mathrm{~W} / \mathrm{cm}^{2}-20 \%\right)$ and G3 $(0.6$ $\left.\mathrm{W} / \mathrm{cm}^{2}-20 \%\right)$, with periods of treatment at 24,48 and 72 hours. The cell viability assay was analyzed by the MTT method and gene modulation was analyzed by RT-qPCR method. Results: After the comparative analysis between groups, only G2 and G3 (48-hour) presented statistically significant differences in relation to the control. In relation to the gene expression, the selection of the groups analyzed was delimited according to the comparative analysis of the values obtained by the MTT test. After the achievement of RT-qPCR, it could be observed that in $\mathrm{G} 2$ the amount of VEGF gene transcripts increased by 1.125 -fold compared to endogenous controls, and increased 1.388-fold in G3. The IL-6 gene, on the other hand, had its transcripts reduced in both G2 $\left(5.64 \times 10^{-9}\right)$ and $\mathrm{G} 3\left(1.91 \times 10^{-6}\right)$. Conclusion: Pulsed ultrasound in L929 fibroblasts showed a significant biostimulatory effect in the 48-hour period, with increased cell viability, and the same effect in the modulation of gene expression related the neovascularization and inflammation, mediating the acceleration of the tissue repair cascade.
\end{abstract}

Keywords: Rehabilitation. Fibroblasts. Gene expression. Regeneration. Ultrasonic therapy. 


\section{Resumo}

Introdução: Na reabilitação de lesões musculoesqueléticas, o ultrassom é amplamente utilizado na prática clínica. Objetivo: Avaliar os efeitos da terapia ultrassônica pulsada sobre a viabilidade e modulação de genes envolvidos nos processos de inflamação (IL-6) e neovascularização (VEGF) de fibroblastos L929. Métodos: Para irradiação com ultrassom, as células foram subdivididas em grupos: G1 (sem irradiação), G2 (0,3 W/ $/ \mathrm{cm}^{2}$ $20 \%)$ e $\mathrm{G} 3\left(0,6 \mathrm{~W} / \mathrm{cm}^{2}-20 \%\right)$, com períodos de tratamento de 24,48 e 72 horas. O ensaio de viabilidade celular foi analisado pelo método MTT e a modulação gênica pelo método RTqPCR. Resultados: Após a análise comparativa entre os grupos, apenas G2 e G3 (48 horas) apresentaram diferenças estatisticamente significantes em relação ao controle. Em relação à expressão gênica, a seleção dos grupos analisados foi delimitada de acordo com a análise comparativa dos valores obtidos pelo teste MTT. Após a obtenção do RT-qPCR, pôde-se observar que no G2 a quantidade de transcritos do gene VEGF aumentou 1,125 vezes em relação aos controles endógenos e 1,388 vezes no G3. O gene IL-6, por outro lado, teve seus transcritos reduzidos tanto no $G 2\left(5,64 \times 10^{-9}\right)$ quanto no $G 3$ $\left(1,91 \times 10^{-6}\right)$. Conclusão: $O$ ultrassom pulsado em fibroblastos L929 apresentou efeito bioestimulador significativo no período de 48 horas, com aumento da viabilidade celular, e o mesmo efeito na modulação da expressão gênica relacionou neovascularização e inflamação, mediando a aceleração da cascata de reparação de tecidos.

Palavras-chave: Reabilitação. Fibroblastos. Expressão genética. Regeneração. Terapia ultrassônica.

\section{Introduction}

In the clinical practice, ultrasound is widely used in the most diverse skeletal muscle dysfunctions, whether acute or chronic, ${ }^{1,2}$ especially because it is an economical, safe, non-invasive physical procedure , with healing capacity and considered a promising modality as an alternative to surgery. ${ }^{3-6}$

Since 1952, after its implantation by the American Council of Physical Medicine and Rehabilitation, its relation with osteomyoarticular injuries has been a constant target of study. ${ }^{7,8}$ However, clinical practice still adopts a multiplicity of dosimetries, i.e. there is no standardized consensus on the optimal dose response, but there is a gap in the literature between the therapeutic tool, the appropriate dosimetry and the desired cell biomodulation. ${ }^{7-9}$

In general, this feature has thermal properties (continuous wave) and non-thermal (pulsed wave), ${ }^{10,11}$ but the predominance of one or the other is linked to the parameters used in the treatment, since both cannot be completely segmented. ${ }^{10,12}$

In this sense, the interaction of therapeutic ultrasound (TUS) with tissues can increase the permeability of the membranes with substances loading, analgesia, ${ }^{13}$ protein synthesis, ${ }^{14}$ chondrogenesis, osteogenesis, ${ }^{8}$ anti-inflammatory signaling (decrease of leucocytes and macrophages), increase of metabolic reactions, microcirculation stimulation and angiogenesis, and, finally, fibroblastic activation. 3,4

From these meanings, we can highlight more specifically three biological events, which together corroborate in the potentiation of tissue healing. Among them, the activation of fibroblast cells, which is fundamental, because they are present in most tissues and organs of the body, ${ }^{15}$ because they are precursors of collagen and highly metabolic. ${ }^{12-15}$

Moreover, the main mechanosensitive cells are considered for their ability to transform external mechanical excitations into intracellular responses. Thus, by signal capture and mechanotransduction, fibroblasts permeate biological events involving cell proliferation and conformation, cytokine release and gene expression, such as growth factors, collagen, IL-6 and VEGF. ${ }^{15-17}$

The angiogenic potential of the VEGF gene modulates the formation of new blood vessels ${ }^{18}$ and triggers the cascade of anti-inflammatory reactions identified by the multifunctional cytokine IL (interleukin)-6 that regulates the immune syste. ${ }^{19}$

In this context, it is evident the ability of the TUS to trigger bioeffects, but, these are dependent on their wave type and exposure characteristics, ${ }^{20}$ therefore, justified the research relevance of the ideal dose-effect relationship and which spectra of biological changes are achieved, precisely due to the fact that these data are limited in the literature. ${ }^{21}$

In this line of thought, in vitro studies allow more systematic and controlled analyzes concerning the exposure elements of the TUS that interposes the cellular response and how they correlate with the remodeling of lesions. ${ }^{22}$ 
Thus, the objective of this study was to evaluate the effects of low and medium intensity pulsed ultrasonic therapy on the viability and modulation of genes involved in inflammation (IL-6) and neovascularization (VEGF) processes of L929 fibroblast cells.

\section{Methods}

The experiments were developed using mouse connective tissue derived fibroblasts from the L929 strain (ATCC CCL-1 NCTC) and supplied by the Adolfo Lutz-SP Institute, Brazil. The study is characterized as experimental and received approval from the Ethics Committee of the Universidade do Norte do Paraná (UNOPAR), under protocol n. 462.478/2013.

\section{Cell culture}

L929 cells were routinely cultured in $25 \mathrm{~cm}^{2}$ (TPP, Zollstrasse-Switzerland) flasks with MEM medium (Minimum Essential Medium, Gibco TM-Invitrogen Corporation, Grad Island, USA) supplemented with 10\% Bovine Fetal Serum (Gibco ${ }^{\circledR}$, by Life Technologies) and $1 \%$ antibiotic-antimycotic (Gibco ${ }^{\circledR}$, by Life Technologies), maintained in $5 \% \mathrm{CO}^{2}$ incubator at $37^{\circ} \mathrm{C}$ (Thermo Forma Scientific, Waltham, MA).

The cells used in this experiment had the replacement of the culture medium every 48 hours and followed the recommendations for use for the in vitro toxicity test contained in ISO 10993-5.

\section{Ultrasound}

Ultrasonic exposure was performed with an equipment of the brand $\mathrm{KLD}^{\circledR}$ - (Biossistemas Equipamentos Eletrônicos Ltda.), Avatar III model, with a head of $1 \mathrm{MHz}$ and effective radiation area (ERA) of $1 \mathrm{~cm}^{2}$, duly calibrated by the manufacturer.

\section{Ultrasonic irradiation}

After obtaining $80 \%$ confluency, cultures of L929 cells were subcultured into 12-well, $24 \mathrm{~mm}$ diameter TPP plates at a density of $1 \times 10^{5}$ cells $/ \mathrm{ml}$. Subsequently, they remained for 24 hours at rest for sedimentation, and then separated into the following groups to perform the ultrasonic exposure: G1 - Control (did not receive irradiation), G2 $-0.3 \mathrm{~W} / \mathrm{cm}^{2}$ with a pulse rate of $20 \%(2: 8$ work cycle), and $\mathrm{G} 3-0.6 \mathrm{~W} / \mathrm{cm}^{2}$ with a pulse rate of $20 \%$ (2:8 work cycle).

To obtain adequate coupling of the ultrasound interface (distance from the cell layer to the transducer: $18 \mathrm{~mm}$ ) and propagation of the mechanical wave, the volumes of the wells were filled with MEM medium to the edge, and each irradiated well, always kept in the same relative to the face of the ultrasound transducer.

As for the application time, the irradiation was carried out for 2 minutes in each well, respecting the relation between area and age, at room temperature, in the intervals of 24, 48 and 72 hours. The experiment was carried out in triplicate for analysis of viability and in triplicate for gene expression.

\section{MTT Assay}

Viability experiments were evaluated by the MTT assay [3-(4,5-dimethylthiazole)-2,5-diphenyltetrazolium bromide].L929 cell cultures received ultrasonic irradiation at the 24, 48 and 72 hour intervals, and after 24 hours of each irradiation MTT test was performed according to the following assay: after removal of the MEM medium, each well received $500 \mu \mathrm{L}$ of MTT, a final concentration of $0.5 \mathrm{mg} / \mathrm{mL}$ and incubated for 1 hour at $37^{\circ} \mathrm{C}$ in $5 \% \mathrm{CO}^{2}$ atmosphere. Then, $500 \mu \mathrm{L}$ of Dimethyl Sulfoxide (DMSO) was added to each well. The plates were allowed to stir for 15 minutes to solubilize the formazan crystals. Its concentration was quantified spectroscopically by means of a microplate reader (SpectraCount - Packards Istrument, Germany) at wavelength of $546 \mathrm{~nm}$.

\section{Extraction of RNA and Conversion to cDNA}

For extraction of total RNA the Cells-to-cDNA ${ }^{\mathrm{TM}}$ || $\mathrm{Kit}^{\circledR}$ (I Life Technologies Corporation) was used according to the manufacturer's instructions. After extraction, the RNA was quantified in NanoDrop Lite spectrophotometer (Thermo Scientific). RNA extraction was performed 24 hours after the last irradiation, followed by the RT-qPCR polymerase chain reaction.

In order to minimize variations in the performance of reverse transcriptase and the possibility of the Monte Carlo effect, three distinct reactions of cDNA synthesis were performed for each experiment, whose products were incorporated to obtain a single mixture for each sample in its respective condition of cultivation. 


\section{Real-Time Quantitative Polymerase Chain Reaction (RT-qPCR)}

Real-time polymerase chain reaction (PCR) was performed on a StepOne Plus System thermocycler (Applied Biosystems) under the following conditions: 10 minutes at $95^{\circ} \mathrm{C}, 40$ cycles of 15 seconds at $95^{\circ} \mathrm{C}$ and 60 seconds at $60^{\circ} \mathrm{C}$ followed by the melting curve under the following conditions: $95^{\circ} \mathrm{C}$ for 15 seconds, $60^{\circ} \mathrm{C}$ for 60 seconds and to finish $95^{\circ} \mathrm{C}$ for 15 seconds.

The final $20 \mu \mathrm{l}$ reaction contained $10 \mu \mathrm{l}$ of the TaqMan ${ }^{\circledR}$ Universal Master Mix II (Applied Biosystems), $1 \mu \mathrm{l}$ of the $\operatorname{TaqMan}^{\circledR}$ Gene Expression Assays-primer (Applied Biosystem), $8 \mu \mathrm{l}$ of ultra-pure $\mathrm{H} 2 \mathrm{O}$ and $1 \mu \mathrm{l}$ of cDNA.

To determine the relative expression of the genes of interest (VEGF: Mm01281449_m1-Mouse and IL-6: Mm 00446190_m1-Mouse) in the different conditions evaluated, the threshold $(\mathrm{Ct})$ of each sample was initially obtained by fluorescence. Endogenous genes were $\beta$-Actin gene (Mm 00607939_s1 - Mouse) and GAPDH (Mm 99999915_g1 - Mouse). In the sequence, the mean $\mathrm{Ct}$ was calculated between the target and endogenous genes of each sample, obtaining $\Delta \mathrm{Ct}$. To obtain the values in the control situation (no treatment) were used as a reference for comparison, and the calculations were normalized from the endogenous $\beta$-Actin gene ( $\mathrm{Mm}$ 00607939_s1 - Mouse) and GAPDH (Mm 99999915_g1 - Mouse). Due to the low applicability of the direct and unique use of the $\Delta \mathrm{Ct}$ values, the relative quantity (RQ) $2^{-\Delta \Delta C T}$ based on its own mathematical model of relative quantification of data obtained by real-time $\mathrm{PCR}^{23-25}$ with correction of efficiency. Only values of $\mathrm{Cq}$ (quantification cycle) with a variation of \pm 0.5 between the reaction triplicates were considered.

\section{Statistical analysis}

Data were expressed as values of mean and standard deviation, with normality verified by the Shapiro-Wilk test. To compare and verify the statistically significant differences between the groups, the Kruskal Wallis test and Dunn's post hoc test were used, and the Friedman test was used for the comparison between the time evaluations. In the statistical analysis, the program GraphPadPrism 6.0 (GraphPad Software, San Diego, CA, USA) was used.

\section{Results}

After the comparative analysis between the different dosages, only the groups G2 and G3 presented statistically significant differences in relation to their respective control group $(p<0.05)$ in the period of 48 hours, according to Figure 1.

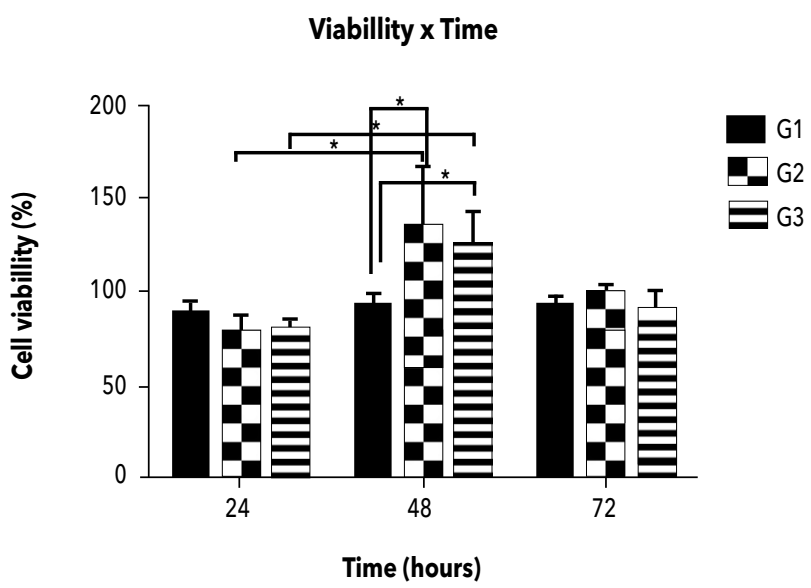

Figure 1 - Comparison of percentages of cell viability intra and between groups in the different treatment periods $(24,48$ and 72 hours).

Note: Values presented in mean and standard deviation (mean \pm SD). *Statistically significant difference $(p<0.05)$ between 24 and 48 hours and groups from the 48-hour period with G1 (control) and G2 (0.3 W/ $\mathrm{cm}^{2}-20 \%$ ), as well as G1 (control) and G3 $\left(0.6 \mathrm{~W} / \mathrm{cm}^{2}-20 \%\right)$.

Figure 1 shows the intra-group data analysis, focusing on the time variable, in which the cell viability reached growth in relation to the control with significant difference in the $\mathrm{G} 2$ group from the first to the second evaluation (24 to 48 hours) and in G3, at the same time intervals.

In relation to the gene expression, the selection of the groups analyzed was delimited according to the comparative analysis of the values obtained by the MTT test, in which only G2 and G3 obtained statistically significant results in the second evaluation (48 hours).

Thus, after the achievement of RT-qPCR, it can be observed that in group G2, the amount of VEGF gene transcripts increased by 1.125 -fold compared to endogenous controls and, with a prominent behavior in group G3, the relative expression increased by about 
1.388 times. It is noteworthy that both gene expressions were relatively superior to the proportionality of their normalizing genes (Figure 2). On the other hand, the IL-6 gene had its transcripts reduced in both the $G 2$ and G3 groups, so that the decrease in the first was $5.64 \mathrm{x}$ $10^{-9}$ and in the second, $1.91 \times 10^{-6}$ fold lower than their reference genes (Figure 2).



(A)

48 hours
However, it is important to note that the relative expressions of VEGF and IL-6 when compared to the cellular viability of their groups, especially when observed in the G3 group may suggest that the ultrasound did not deleteriously act on the cells and that in none of these groups did the fibroblasts remain inert to the ultrasonic action.



48 hours

Figure 2 - Relative gene expression in groups G1 (control), G2 (0.3-20\%) and G3 (0.6-20\%) in time 48 hours. (A) VEGF gene expression and (B) IL-6 gene expression.

\section{Discussion}

In physical therapy, ultrasound therapy is usually used for the purpose of tissue repair by triggering various biomodulatory effects on the exposed tissue, although such responses are tied to a series of combinations between intensity, pulse rate, frequency, treatment time, cell type and culture, leading to a relationship between responses and dosimetry, where some parameters are more effective than others. ${ }^{26-28}$

At first, the combination of mechanisms between acoustic transmission energy and stable cavitation act as a trigger, exciting the cell as a whole through the membrane. However, not all phases of the cycle starting with external excitement to the final chain, such as gene release, are fully understood.

Currently, ultrasound is known to promote various effects on tissues to biological factors, such as increased metabolism, angiogenesis, tissue extensibility, tissue regeneration, cell membrane permeability, and growth factors, counteracting the reduction of mediators of inflammatory process, free radicals and bacterial action. Together, all these factors provide relief in pathological signs and symptoms, with the advancement in the speed of healing and quality of the newly formed tissue, justifying their notorious applicability in physical therapy by seeking analgesia, edema reduction and healing. At first, the combination of acoustic transmission energy mechanisms and stable cavitation act as a trigger, exciting the cell as a whole through the membrane. However, not all stages of the cycle and details of basic science that begin with external excitement to the final chain are fully understood and described. 2,9,10,16,17,28

In this sense, the results found in the present study showed that only the G2 and G3 groups, at 48 hours, presented cell growth statistically significant in relation to its respective control group ( $p<0.05$ ), confirming the aforementioned theory. Under certain conditions, however, ultrasonic mechanical stimulation can improve state of cell culture and, consequently, its proliferation. ${ }^{29}$ 
In in vitro cultured $L 929$ fibroblasts, Bertin et al. ${ }^{3}$ observed, in similar methodology and cell type, the increase in the number of viable cells, with intensities of 0.2 and $0.4 \mathrm{~W} / \mathrm{cm}^{2}$ and pulses of 10 or $20 \%$, as well as Oliveira et al. ${ }^{30}$ in the 72 -hours period in schedules of 0.2 and $0.6 \mathrm{~W} / \mathrm{cm}^{2}-10$ or $20 \%$, and Oliveira et al. ${ }^{4}$ in 48 and 72 hours, with dose of $0.5 \mathrm{~W} / \mathrm{cm}^{2}-10 \%$.

Furthermore, other authors also achieved statistically significant fibroblast expansion in human cells $(1 \mathrm{MHz}$; 140 ou $200 \mathrm{~mW} / \mathrm{cm}^{2} ; 20 \%$ ), ${ }^{31}$ of murine mice (1 MHz; 307 and $\left.46 \mathrm{~mW} / \mathrm{cm}^{2} ; 75 \%\right)^{32}$ or in other cell types such as rat gingival epithelial tissue $(3 \mathrm{MHz} ; 160$ or $240 \mathrm{~mW} /$ $\mathrm{cm}^{2} ; 24,72$ and 120 hours), ${ }^{33}$ human chondrocytes (1.5 $\left.\mathrm{MHz} ; 30 \mathrm{~mW} / \mathrm{cm}^{2}\right){ }^{34} \mathrm{C} 2 \mathrm{C} 12$ myoblasts $\left(30 \mathrm{~mW} / \mathrm{cm}^{2}\right.$; 20\%; 144 and 192 hours $)^{35}$ and rabbit intervertebral disc cells $\left(1.5 \mathrm{MHz} ; 7.5,15,30 \mathrm{~mW} / \mathrm{cm}^{2} ; 20 \% ; 120\right.$ hours). ${ }^{36}$

Despite the relevance of the human cell lineage, however, rodent derivatives such as ling fibroblasts, Chinese hamster ovary, osteoblasts, keratinocytes, chondrocytes, mouse myocytes, murine hepatocytes and primates such as monkey kidney fibroblasts (Vero line) are chosen as a first choice for safety reasons, for the wide knowledge of the conditions of cultivation and use, as well as their physiological and genetic patterns. ${ }^{37-39}$

On the other hand, in groups G2 in 24 hours and G3 in 24 and 72 hours, maintenance was observed with very few variations or small reduction in cellular viability in relation to their respective controls, although it was not statistically significant. At the same time, other authors detected similar behaviors such as Udroiu et al. ${ }^{40}(1 \mathrm{MHz}$; $1,11.8,15.2$ and $19.3 \mathrm{~mW} / \mathrm{cm}^{2} ; 75 \%$ ) and Zhang et al. ${ }^{41}$ $\left(0.5 \mathrm{MHz} ; 3,97-11 \mathrm{~mW} / \mathrm{cm}^{2} ; 10-50 \%\right)$ in rat fibroblasts, and Mostafa et al. ${ }^{42}\left(1.5 \mathrm{MHz} ; 30 \mathrm{~mW} / \mathrm{cm}^{2}\right)$ and Harle et al. ${ }^{43}\left(3 \mathrm{MHz} ; 140-990 \mathrm{~mW} / \mathrm{cm}^{2}\right)$ in human fibroblasts.

Not unlike fibroblastic cells, other strains reduced or not undergone changes in their proliferation by ultrasonic exposure, as in osteoblasts (1.5 MHz; $30 \mathrm{~mW}$ / $\left.\mathrm{cm}^{2} ; 20 \%\right){ }_{1}^{44}$ in stem cells ( $1 \mathrm{MHz} ; 0.3$ e $0.5 \mathrm{~W} / \mathrm{cm}^{2} ; 20 \%$; 48 horas $^{39}$ and, finally, in synovial membrane cultures of rabbits ( $3 \mathrm{MHz} ; 30 \mathrm{~mW} / \mathrm{cm}^{2} ; 20 \%$ ). ${ }^{45}$ Still on the present theme, Uenaka et al. ${ }^{46}$ adds that the density of cells seeded in the wells interferes directly in the result, be it viability or gene modulation, due to the lack of cellcell interaction, in small concentrations or with nutrient shortage in populations. After all, in their studies with chondrocytes and pulsed ultrasound $(1.5 \mathrm{MHz} ; 30 \mathrm{~mW} /$ $\mathrm{cm}^{2} ; 20 \%$ ), each used density, 1,2 , and $4 \times 10^{7}$ cells $/ \mathrm{cm}^{2}$ showed divergent results.
In addition, the sonolysis of the aqueous medium by the pulsed ultrasonic waves may allow the release of free radicals and these byproducts of the reaction may boost apoptosis in vitro and changes in intracellular metabolism. ${ }^{47}$

Bohari et al. ${ }^{48}$ suggested that there is a tendency to induce gene expression in rat fibroblasts using a $20 \%$ pulsed ultrasonic action compared to human fibroblasts, although increasing DNA analysis has not undergone genetic modulation using ultrasound. ${ }^{49}$ As for the modulation of the VEGF and IL-6 genes in the 48-hour period, that is, after two irradiations, the data indicate a stimulatory effect on the expression of the first and suppression of the second in groups $\mathrm{G} 2$ and $\mathrm{G} 3$ relative to their endogenous genes in the control group.Thus, according to our findings, Doan et al. ${ }^{31}$ reported that in their experiments in in vitro fibroblasts with pulsed ultrasound (10,20 and 30\%) at $1 \mathrm{MHz}$ and intensities at $5,15,30$ and $50 \mathrm{~mW} / \mathrm{cm}^{2}$, the production in interleukin 1 and 6 transcripts was very low, whereas VEGF was positively stimulated, mainly at 0.1 and $0.4 \mathrm{~W} / \mathrm{cm}^{2}$.

Similarly, more specifically on the induction of angiogenic factors under direct ultrasonic action in vitro, other authors described their induction $(1 \mathrm{MHz}$; $0.1,0.4,0.7$ and $1 \mathrm{~W} / \mathrm{cm}^{2} ; 20 \%$ ) fibroblasts in disks with water, where there was an increase between 67 and $100 \%$ of angiogenic response. ${ }^{50}$ This also occurred in real-time PCR analyzes of osteoblasts, after 24, 48 and 72 hours after irradiation at doses of $0.1,0.3$ and $0.5 \mathrm{~W} /$ $\mathrm{cm}^{2}$ in $1 \mathrm{MHz}-25 \%$ and pre-osteoblasts ( $1 \mathrm{MHz} ; 30 \mathrm{~mW}$ / $\left.\mathrm{cm}^{2} ; 20 \%\right) .51,52$ Additionally, in experiments on rabbit chondrocytes $\left(1.5 \mathrm{MHz} ; 30 \mathrm{~mW} / \mathrm{cm}^{2} ; 20 \%\right)$ the VEGF gene grew by 1.532 times, $^{53}$ and in vivo the expression was four fold higher in the tendon of sheep treated with $30 \mathrm{~mW} / \mathrm{cm}^{2}$ (1.5 MHz; 20\%) than in untreated animals. ${ }^{54}$ In addition, Ichijo et al. ${ }^{55}$ demonstrated through histological analysis in mice in vivo that pulsed ultrasound therapy significantly increased the number of blood vessels in the treated regions.

Finally, concerning the modulation of interleukin transcripts, Reher et al., ${ }^{56}$ unlike our findings, do not describe any reduction or change in the secretion of IL-6 cytokines in fibroblasts ( $1 \mathrm{MHz} ; 0.1 ; 0.4 ; 0.7$; and $1 \mathrm{~W} /$ $\left.\mathrm{cm}^{2} ; 20 \%\right)$. In contrast, osteoblasts cultivated primarily and treated with UST $\left(1 \mathrm{MHz}, 600 \mathrm{~mW} / \mathrm{cm}^{2} ; 20 \%\right)$ showed a significant attenuation in IL-6 concentrations after 72 and 96 hours, ${ }^{57}$ accelerating the onset of the first phase of the healing cascade, by of the anti-inflammatory 
properties of ultrasound. ${ }^{58}$ These findings make it evident that although the ultrasound has been the subject of long-term study, the literature generally does not present a standardization between the ideal and safe dosage to obtain the desired biomodulatory responses. ${ }^{9}$ After all, since this therapeutic resource is usually used in physical therapy, contributing to the process of tissue regeneration requires the investigation and elucidation of this theme. ${ }^{59}$

A systematic review gathered studies involving therapeutic ultrasound applied to fibroblastic cells in vitro and concluded that the biophysical characteristics of this equipment can produce the most diverse biological reactions. However, they add that the available literature is still insufficient to state with certainty which is the best dosimetry to be chosen in order to obtain the most effective and safe results, confirming the need for further investigation on this subject. ${ }^{9}$

As a way of exemplifying the applicability in in vivo studies, in the investigations of Fu et al. ${ }^{59}$ low-intensity pulsed ultrasound restored mechanical strength and collagen alignment in the tendons of rat patellar injury models in parallel with bone-tendon junction healing in rabbits. ${ }^{60}$ Collaborating with the findings mentioned above, Best et al. ${ }^{61}$ affirm in a systematic review that although not standardized, there is support in scientific evidence for the treatment of soft tissue injuries (tendon, muscle, ligament and bone-tendon junction) with pulsed ultrasound and specifically in tendons and ligaments. Recovery has higher tensile strength, stiffness and energy absorption, better organization and amount of collagen fibers when compared to untreated tissues.

Although the in vitro findings cannot be directly extrapolated to clinical practice, they collaborate in the understanding at the molecular level of the possible mechanisms of action of the ultrasound in different experimental conditions. Thus, the findings of this study suggest that low-dose pulsed ultrasound already has biological responses concerning better vascularization capacity, cell growth and inflammatory reduction, reducing the possible side risks of high intensities. So, cell-culturebased investigations are fundamental for complementing in vivo research, especially when assessing the potential of ultrasound, by allowing more rigid controls over several variables, with the possibility of more systematic questioning. This allows to contribute with the prevention of possible damages to the patient or optimization of results within the physical therapy. ${ }^{3,4,9,16,21,28,62}$

\section{Conclusion}

The results showed that the pulsed ultrasonic therapy

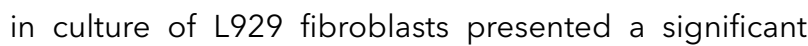
biostimulatory effect in the period of 48 hours in the dosages of 0.3 and $0.6 \mathrm{~W} / \mathrm{cm}^{2}$ at $20 \%$ and $1 \mathrm{MHz}$, with cellular viability growth, as well as, it may be suggested that it acts on the modulation of gene expression by increasing the level of Endothelial Growth Factor (VEGF) secretion and reducing the transcripts of the Interleukin 6 (IL-6) gene, mediating the acceleration of the cascade of tissue repair.

The limitations of this study are summarized in what in spite of collaborating in understanding the mechanism of action experimental conditions in vitro may not represent cellular responses in vivo, therefore, they cannot be completely generalizable in humans.

\section{Acknowledgments}

The authors would like to express their gratitude for the financial support of the National Foundation for the Development of Private Higher Education (FUNADESP) and the National Council for Scientific and Technological Development (CNPq). Description: UNIVERSAL EDITAL - CNPQ Process: 442412 / 2014-2 Call: MCTI / CNPQ / Universal 14/2014.

\section{Authors' contributions}

Each author contributed individually and significantly to the development of the manuscript. PDOP began to approach the research problem and participated in all stages: project construction, bibliographic research, data collection, data analysis, discussion of results, conclusion and writing of the manuscript. DAAPO and RFO participated in all stages, from project construction, data collection, data analysis, discussion of results, writing and critical review of the manuscript. LDB and FBPM participated in data collection and analysis. RCPF participated in guiding all steps, from project construction, data collection, data analysis, discussion of results, manuscript writing and final review. All authors contributed strongly to the study and were responsible for all aspects of the work, and all of them have approved the final version of this article. 


\section{References}

1. Spratt Jr HG, Levine D, Tillman L. Physical therapy clinic therapeutic ultrasound equipment as a source for bacterial contamination. Physiother Theory Pract. 2014;30(7):507-11. DOI

2. Tsai WC, Tang ST, Liang FC. Effect of therapeutic ultrasound on tendons. Am J Phys Med Rehabil. 2011;90(12):1068-73. DOI

3. Bertin LD, Pires-Oliveira DAA, Oliveira PD, Serpeloni JA, Szezerbaty SKF, Santos JPM, et al. The influence of ultrasonic radiation of low intensity in cultured fibroblast cells. Man Ther Posturology Rehabil J. 2015;13:306. DOI

4. Oliveira PD, Oliveira DAAP, Martinago CC, Frederico RCP, Soares CP, Oliveira RF. Effect of low-intensity pulsed ultrasound therapy on fibroblasts cell culture. Fisioter Pesqui. 2015;22(2):112-8. Full text link

5. Harrison A. Clinical fracture treatment with lipus (lowintensity pulsed ultrasound). Orthopaedic Proceedings. 2021; 103-B(Supp 2):94. Full text link

6. Lai WC, Iglesias BC, Mark BJ, Wang D. Low-intensity pulsed ultrasound augments tendon, ligament, and bone-soft tissue healing in preclinical animal models: A systematic review. Arthroscopy. 2021; S0749-8063(21)00152-3. DOI

7. Kaur $H$, Uludağ $H$, El-Bialy T. Effect of nonviral plasmid delivered basic fibroblast growth factor and low intensity pulsed ultrasound on mandibular condylar growth: a preliminary study. Biomed Res Int. 2014;2014:426710. DOI

8. Nam KW, Yelseo D, Heekim M. Pulsed and continuous ultrasound increase chondrogenesis through the increase of heat shock protein 70 expression in rat articular cartilage. J Phys Ther Sci. 2014;26(5):647-50. DOI

9. Oliveira PD, Pires-Oliveira DAA, Bertin LD, Szezerbaty SKF, Oliveira RF. The effect of therapeutic ultrasound on fibroblast cells in vitro: the systematic review. Arch Med Deporte. 2018;35(1):50-5. Full text link

10. Baker KG, Robertson VJ, Duck FA. A review of therapeutic ultrasound: biophysical effects. Phys Ther. 2001;81(7):1351-8. DOI
11. Catapani LB, Gonçalves AC, Candeloro NM, Rossi LA, Guirro ECO. Influence of therapeutic ultrasound on the biomechanical characteristics of the skin. J Ther Ultrasound. 2016;4:21. DOI

12. Jesus GS, Ferreira AS, Mendonça AC. Fonoforese $x$ permeação cutânea. Fisioter Mov. 2006;19(4):83-8. Full text link

13. Guirro ECO, Angelis DF, Sousa NTA, Guirro RRJ. Combination of therapeutic ultrasound with antibiotics interfere with the growth of bacterial culture that colonizes skin ulcers: An in-vitro study. Ultrason Sonochem. 2016;32:284-9. DOI

14. Maddi A, Hai H, Ong ST, Sharp L, Harris M, Meghji S. Long wave ultrasound may enhance bone regeneration by altering OPG/RANKL ratio in human osteoblast-like cells. Bone. 2006;39 (2):283-8. DOI

15. Frairia R, Berta L. Biological effects of extracorporeal shock waves on fibroblasts. A review. Muscles Ligaments Tendons J. 2012;1(4):138-47. Full text link

16. Bertin LD, Poli-Frederico RC, Oliveira DAAP, Oliveira PD, Pires FB, Silva AFS, et al. Analysis of cell viability and gene expression after continuous ultrasound therapy in L929 fibroblast cells. Am J Phys Med Rehabil. 2019;98(5):369-72. DOI

17. Perrucini PDO, Poli-Frederico RC, Pires-Oliveira DAA, Bertin LD, Pires FB, Shimoya-Bittencourt W, et al. Anti-inflammatory and healing effects of pulsed ultrasound therapy on fibroblasts. Am J Phys Med Rehabil. 2020;99(1):19-25. DOI

18. Martignago CCS, Oliveira RF, Pires-Oliveira DAA, Oliveira PD, Soares CP, Monzani PS, et al. Effect of low-level laser therapy on the gene expression of collagen and vascular endothelial growth factor in a culture of fibroblast cells in mice. Lasers Med Sci. 2015;30(1):203-8. DOI

19. Mihara $M$, Hashizume $M$, Yoshida $H$, Suzuki $M$, Shiina $M$. IL-6/IL-6 receptor system and its role in physiological and pathological conditions. Clin Sci (Lond). 2012;122(4):143-59. DOI

20. GT Haar. Therapeutic applications of ultrasound. Prog Biophys Mol Biol. 2007;93(1-3):111-29. DOI

21. Patel US, Ghorayeb SR, Yamashita Y, Atanda F, Walmsley AD, Scheven BA. Ultrasound field characterization and bioeffects in multiwell culture plates. J Ther Ultrasound. 2015;3:8. DOI 
22. Samuels JA, Weingarten MS, Margolis DJ, Zubkov L, Sunny $Y$, Bawiec CR, et al. Low-frequency $(<100 \mathrm{kHz})$, low-intensity $\left(<100 \mathrm{~mW} / \mathrm{cm}^{2}\right)$ ultrasound to treat venous ulcers: a human study and in vitro experiments. J Acoust Soc Am. 2013;134(2): 1541-7. DOI

23. Livak KJ, Schmittgen TD. Analysis of relative gene expression data using real-time quantitative PCR and the $2^{-\triangle \triangle C T}$ Method. Methods. 2001;25(4):402-8. DOI

24. Schmittgen TD, Livak KJ. Analyzing real-time PCR data by the comparative C(T) method. Nat Protoc. 2008;3(6):1101-8. DOI

25. VanGuilder HD, Vrana KE, Freeman WM. Twenty-five years of quantitative PCR for gene expression analysis. Biotechniques. 2008;44(5):619-26. DOI

26. Paliwal S, Mitragotri S. Therapeutic opportunities in biological responses of ultrasound. Ultrasonics. 2008;48(4):271-8. DOI

27. Tabuchi Y, Sugahara Y, Ikegame M, Suzuki N, Kitamura Kl, Kondo T. Genes responsive to low-intensity pulsed ultrasound in MC3T3-E1 preosteoblast cells. Int J Mol Sci. 2013;14(11):2272140. Full text link

28. Watson T. Ultrasound in contemporary physiotherapy practice. Ultrasonics. 2008;48(4):321-9. DOI

29. Hormozi-Moghaddam Z, Mokhtari-Dizaji M, Nilforoshzadeh MA, Bakhshandeh M. Low intensity ultrasound to induce proliferation and collagen I expression of adipose-derived mesenchymal stem cells and fibroblast cells in co-culture. Measurement. 2021;167:108280. DOI

30. Oliveira RF, Oliveira DAAP, Machado AHA, Silva NS, Magini $M$, Pacheco-Soares $C$. Assessment of fibroblast cells submitted ultrasonic irradiation. Cell Biol Int. 2008;32(10):1329-35. DOI

31. Doan N, Reher P, Meghji S, Harris M. In vitro effects of therapeutic ultrasound on cell proliferation, protein synthesis and cytokine production by human fibroblasts, osteoblasts and monocytes. J Oral Maxillofac Surg. 1999;57(4):409-19. DOI

32. Grimaldi P, Giambattista LD, Giordani S, Udroiu I, Pozzi D, Gaudenzi S, et al. Ultrasound-mediated structural changes in cells revealed by FTIR spectroscopy: A contribution to the optimization of gene and drug delivery. Spectrochim Acta A Mol Biomol Spectrosc. 2011;84(1):74-85. DOI
33. Iwanabe Y, Masaki C, Tamura A, Tsuka S, Mukaibo T, Kondo $Y$, et al. The effect of low-intensity pulsed ultrasound on wound healing using scratch assay in epithelial cells. J Prosthodont Res. 2016;60(4):308-14. DOI

34. Korstjens CM, van der Rijt RHH, Albers GHR, Semeins CM, Klein-Nulend J. Low-intensity pulsed ultrasound affects human articular chondrocytes in vitro. Med Biol Eng Comput. 2008;46(12):1263-70. DOI

35. Chan YS, Hsu KY, Kuo CH, Lee SD, Chen SC, Chen WJ, et al. Using low-intensity pulsed ultrasound to improve muscle healing after laceration injury: an in vitro and in vivo study. Ultrasound Med Biol. 2010;36(5):743-51. DOI

36. Iwashina $T$, Mochida J, Miyazaki T, Watanabe $T$, Iwabuchi $\mathrm{S}$, Ando $\mathrm{K}$, et al. Low-intensity pulsed ultrasound stimulates cell proliferation and proteoglycan production in rabbit intervertebral disc cells cultured in alginate. Biomaterials. 2006;27(3):354-61. DOI

37. Bradley MO, Bhuyan B, Francis MC, Langenbach R, Peterson A, Huberman E. Mutagenesis by chemical agents in V79 Chinese hamster cells: a review and analysis of the literature. A report of the Gene-Tox Program. Mutat Res. 1981;87(2):81-142. DOI

38. Doyle A, Griffiths JB. Cell and tissue culture: Laboratory procedures in biotechnology. Nova Jersey: John Wiley \& Sons Inc.; 1999.

39. Zucco F, De Angelis I, Testai E, Stammati A. Toxicology investigations with cell culture systems: 20 years after. Toxicol In Vitro. 2004;18(2):153-63. DOI

40. Udroiu I, Domenici F, Giliberti C, Bedini A, Palomba $R_{t}$ Luongo $F$, et al. Potential genotoxic effects of low-intensity ultrasound on fibroblasts, evaluated with the cytokinesis-block micronucleus assay. Mutat Res Genet Toxicol Environ Mutagen. 2014;772:20-4. DOI

41. Zhang $Y$, Tachibana R, Okamoto A, Azuma T, Sasaki A, Yoshinaka $K$, et al. Ultrasound-mediated gene transfection in vitro: Effect of ultrasonic parameters on efficiency and cell viability. Int J Hyperthermia. 2012;28(4):290-9. DOI

42. Mostafa NZ, Uludag H, Dederich DN, Doschak MR, El-Bialy $\mathrm{TH}$. Anabolic effects of low-intensity pulsed ultrasound on human gingival fibroblasts. Arch Oral Biol. 2009;54(8):743-8. DOI 
43. Harle J, Salih V, Mayia F, Knowles JC, Olsen I. Effects of ultrasound on the growth and function of bone and periodontal ligament cells in vitro. Ultrasound Med Biol. 2001;27(4):579-86. DOI

44. Hasegawa T, Miwa M, Sakai Y, Niikura T, Kurosaka M, Komori T. Osteogenic activity of human fracture haematoma-derived progenitor cells is stimulated by low-intensity pulsed ultrasound in vitro. J Bone Joint Surg Br. 2009;91(2):266-70. DOI

45. Nakamura T, Fugihara S, Yamamoto-Nagata K, Katsura T, Inubushi T, Tanaka E. Low-intensity pulsed ultrasound reduces the inflammatory activity of synovitis. Ann Biomed Eng. 2011;39(12):2964-71. DOI

46. Uenaka K, Imai S, Ando K, Matsusue Y. Relation of lowintensity pulsed ultrasound to the cell density of scaffold-free cartilage in a high-density static semi-open culture system. J Orthop Sci. 2010;15(6):816-24. DOI

47. Feril Jr LB, Kondo T. Biological effects of low intensity ultrasound: the mechanism involved, and its implications on therapy and on biosafety of ultrasound. J Radiat Res. 2004;45(4):479-89. DO।

48. Bohari SP, Grover LM, Hukins DWL. Pulsed-low intensity ultrasound enhances extracellular matrix production by fibroblasts encapsulated in alginate. J Tissue Eng. 2012;3(1):2041731412454672. DOI

49. Zhou S, Schmelz A, Seufferlein T, Li Y, Zhao J, Bachem MG. Molecular mechanisms of low intensity pulsed ultrasound in human skin fibroblasts. J Biol Chem. 2004;279(52):54463-9. DOI

50. Ramli R, Reher P, Harris M, Meghji S. The effect of ultrasound on angiogenesis: an in vivo study using the chick chorioallantoic membrane. Int J Oral Maxillofac Implants. 2009;24(4):591-6. Full text link

51. Gleizal A, Li S, Pialat JB, Beziat JL. Transcriptional expression of calvarial bone after treatment with low-intensity ultrasound: an in vitro study. Ultrasound Med Biol. 2006;32(10):1569-74. $\mathrm{DOI}$

52. Wang FS, Kuo YR, Wang CJ, Yang KD, Chang PR, Huang YT, et al. Nitric oxide mediates ultrasoundinduced hypoxia-inducible factor- $1 \alpha$ activation and vascular endothelial growth factor-A expression in human osteoblasts. Bone. 2004;35(1):114-23. DOI
53. Kobayashi Y, Sakai D, Iwashina T, Iwabuchi S, Mochida J. Low-Intensity pulsed ultrasound stimulates CELL Proliferation, proteoglycan synthesis and synthesis and expression of growth factor related genes in human nucleus pulposus cell line. Eur Cell Mater. 2009;17:15-22. Full text link

54. Lovric V, Ledger M, Goldberg J, Harper W, Bertollo N, Pelletier $\mathrm{MH}$, et al. The effects of Low-intensity Pulsed Ultrasound on tendon-bone healing in a transosseous-equivalent sheep rotator cuff model. Knee Surg Sports Traumatol Arthrosc. 2013;21(2):466-75. DOI

55. Ichijo S, Shindo T, Eguchi K, Monma Y, Nakata T, Morisue $Y$, et al. Low-intensity pulsed ultrasound therapy promotes recovery from stroke by enhancing angio-neurogenesis in mice in vivo. Sci Rep. 2021;11(1):4958. DOI

56. Reher P, Doan N, Bradnock B, Meghji S, Harris M. Effect of ultrasound on the production of IL-8, basic FGF AND VEGF. Cytokine. 1999;11(6):416-23. DOI

57. Li JK, Chang WH, Lin JC, Ruaan RC, Liuc HC, Sun JS. Cytokine release from osteoblasts in response to ultrasound stimulation. Biomaterials. 2003;24(13):2379-85. DOI

58. Coman M, Hîncu M. Study of bone cells by confocal microscopy in fractures stimulated by ultrasound. Rom J Morph Embryol. 2013;54(2):357-60. Full text link

59. Fu SC, Shum WT, Hung LK, Wong MWN, Qin L, Chan KM. Low-intensity pulsed ultrasound on tendon healing: a study of the effect of treatment duration and treatment initiation. Am J Sports Med. 2008;36(9):1742-9. DOI

60. Lu H, Chen C, Qu J, Chen H, Chen Y, Zheng C, et al. Initiation timing of low-intensity pulsed ultrasound stimulation for tendon-bone healing in a rabbit model. Am J Sports Med. 2016;44(10):2706-15. DOI

61. Best TM, Wilk KE, Moorman CT, Draper OD. Low intensity ultrasound for promoting soft tissue healing: a systematic review of the literature and medical technology. Int Med Rev (Wash D C). 2016;2(11):271. DOI

62. Lv Y, Zhao P, Chen G, Sha Y, Yang L. Effects of low-intensity pulsed ultrasound on cell viability, proliferation and neural differentiation of inducedpluripotent stem cells-derived neural crest stem cells. Biotechnol Lett. 2013;35(12):2201-12. DOI 